\title{
Tumour necrosis factor alpha downregulates human hemojuvelin expression via a novel response element within its promoter
}

\author{
Mohamed Fouda Salama ${ }^{1,2^{*}}$, Henry K Bayele ${ }^{1}$ and Surjit SK Srai ${ }^{1}$
}

\begin{abstract}
Background: Iron homeostasis is chiefly regulated by hepcidin whose expression is tightly controlled by inflammation, iron stores, and hypoxia. Hemojuvelin (HJV) is a bone morphogenetic protein co-receptor that has been identified as a main upstream regulator of hepcidin expression; HJV mutations are associated with a severe form of iron overload (Juvenile haemochromatosis). Currently however, there is no information on how HJV is regulated by inflammation.
\end{abstract}

Methods: To study the regulation of Hjv expression by inflammation and whether Hfe has a role in that regulation, control and LPS-injected wild type and Hfe KO mice were used. Moreover, human hepatoma cells (HuH7) were used to study the effect of IL-6 and TNF-a on HJV mRNA expression.

Results: Here we show that LPS repressed hepatic Hjv and BMPS, while it induced hepcidin 1 expression in wild-type and Hfe KO mice with no effect on hepatic PSMAD 1, 5, 8 protein levels. In addition, exogenous TNF-a ( $20 \mathrm{ng} / \mathrm{mL}$ ) decreased HJV mRNA and protein expression to $40 \%$ of control with no effect on hepcidin mRNA expression in 24 hours. On the other hand, IL-6 induced hepcidin mRNA and protein expression with no effect on HJV mRNA expression levels. Moreover, using the HJV promoter-luciferase reporter fusion construct (HJVP1.2-luc), we showed that the basal luciferase activity of HJVP1.2-luc was inhibited by 33\% following TNF-a treatment of HuH7 transfected cells suggesting that the TNF-a down-regulation is exerted at the transcriptional level. Additionally, mutation of a canonical TNF- alpha responsive element (TNFRE) within HJVP1.2-luc abolished TNF-a response suggesting that this TNFRE is functional.

Conclusions: From these results, we conclude that TNF-a suppresses HJV transcription possibly via a novel TNFRE within the HJV promoter. In addition, the results suggest that the proposed link between inflammation and BMP-SMAD signalling is independent of HJV and BMP ligands.

Keywords: Inflammation, Hemojuvelin, TNF-a

\section{Background}

Inflammatory stimuli are associated with profound alterations in iron homeostasis. Among the most crucial of these changes are the redistribution of iron into reticuloendothelial macrophages, and reduced intestinal iron absorption causing hypoferremia [1-4]. Similar findings have also been reported in mice exposed to endotoxins [5]. The impairment of iron efflux by enterocytes

\footnotetext{
* Correspondence: mohamed.salama@uclmail.net

'Department of Structural and Molecular Biology, Division of Biosciences, University College London, Gower Street, London WC1E 6BT, UK

${ }^{2}$ Department of Biochemistry, Faculty of Veterinary Medicine, Mansoura University, Mansoura, Egypt
}

and reticuloendothelial macrophages is believed to play an important role in host defence against infection and cancer by limiting iron availability for pathogen or cancer cell replication [6,7]. However, one consequence of this is the anaemia of inflammation [8]. Pro-inflammatory cytokines have been shown to modulate the expression of iron transport and storage proteins in a variety of cell types [9-11]. During inflammation, IL-6 induces hepcidin expression through phosphorylation of Stat3 that binds to the Stat3 response element (Stat3RE) within the hepcidin gene promoter [12-14], increases hepcidin expression which in turn decreases intestinal iron absorption

\section{Biomed Central}

(c) 2012 Salama et al.; licensee BioMed Central Ltd. This is an Open Access article distributed under the terms of the Creative Commons Attribution License (http://creativecommons.org/licenses/by/2.0), which permits unrestricted use, distribution, and reproduction in any medium, provided the original work is properly cited. 
[15-19]. To better understand the biology of this, a study showed that humans injected with bacterial lipopolysaccharide (LPS) produced IL-6 within 3 hours, with concomitant increases in circulating hepcidin, and resulting in hypoferremia and reduced serum iron; similar findings were made in humans injected with IL-6 [20,21]. Sterile inflammation induced with turpentine produced similar responses in mice [22,23]. The finding that hepcidin is modulated by inflammatory cytokines or LPS has linked its expression levels to the anaemia of inflammation, otherwise referred to as the anaemia of chronic disease $[17,24]$.

Hemojuvelin, a Bone Morphogenetic Protein (BMP) co-receptor, has been shown to be an important upstream regulator of hepcidin expression [25]. In mice lacking $H j v$, hepcidin induction in response to iron is abrogated. On the other hand, these mice retain the ability to regulate hepcidin in response to inflammation by LPS and IL-6, though to a lesser extent than wild-type animals [26]. Moreover, Hjv expression was downregulated in the liver of mice injected with LPS [26]. These findings suggest that $\mathrm{Hjv}$ may not be directly involved in the hepcidin response to inflammatory stimuli while it is required for hepcidin response to iron. Recently it has been shown that mice lacking hepatic Smad-4 express very low hepcidin levels. In addition, the response of hepcidin to inflammation was abrogated in these mice [27]. Although the proximity of the Stat3RE to a BMP-response element (only 6 nucleotides apart) within the human hepcidin promoter [28] would suggest some amount of transcriptional cross-talk between the Stat3/IL-6 [13] and the Smads/BMP signalling pathways in hepcidin induction; however, this link remains to be clarified.

Evidence for the requirement of Hfe for hepcidin induction during inflammation is conflicting. A group reported that mice lacking $H f e$ do not respond to LPS with increased hepcidin expression as wild-type animals [17]. In another study, the LPS response was significantly different among animals [29]. A recent study showed that Hfe knockout (KO) mice were just as able to regulate hepcidin in response to LPS as wild-type animals [30]. These contradictory findings on the requirement of $\mathrm{Hfe}$ for hepcidin induction during acute inflammation might be partly explained by different concentration of LPS used in these studies, but the study of Hfe $\mathrm{KO}$ mice during the inflammatory response requires further investigation. Moreover, the mechanism of regulation of $H J V$ during inflammation is not clearly understood and needs further investigations. Therefore, this study aimed to understand the mechanism of HJV regulation during inflammation, to investigate the interplay between Hfe and the Smad/BMP pathway in regulating hepcidin expression, and to better understand how important this might be for the changes in iron flux that occur during inflammation.

\section{Methods}

Induction of acute inflammation in mice

Wild-type C57Bl/6 $(\mathrm{n}=10)$ and Hfe $\mathrm{KO}$ (of C57Bl/6 background strain; $\mathrm{n}=10$ ) female mice were supplied by the Comparative Biology Unit at the Royal Free and UCL Medical School, London. All the experimental procedures were conducted in agreement with the UK animals (Scientific Procedures) Act, 1986. Animals were kept in a 12 hour light-dark cycle, provided with water ad libitum, and were fed control diet (RM1 diet; $190 \mathrm{mg}$ $\mathrm{Fe} / \mathrm{kg}$ diet) for six weeks after being weaned (3 weeks of age). Acute inflammation was induced by a single intraperitoneal injection of $5 \mu \mathrm{g}$ LPS/g body weight (Escherichia coli serotype 055:B5, Sigma, UK). Control mice were similarly injected with an equivalent volume of sterile saline solution $(0.09 \% \mathrm{NaCl})$. The mice were terminally anaesthetised with intraperitoneal pentobarbitone sodium (Sagatal, Rhone-Merieux, UK, 90 mg/Kg) 6 hours after injection, the time at which maximal hepcidin induction and $H j v$ repression have been reported $[26,31,32]$. Livers were snap-frozen in liquid $\mathrm{N}_{2}$, and stored at $-80^{\circ} \mathrm{C}$ for real-time PCR analysis, liver iron quantification, and immunoblotting.

\section{Cell culture and treatment with cytokines}

$\mathrm{HuH} 7$ hepatoma cells were obtained from the UCL Institute of Hepatology. The cells were cultured in Dulbecco's Minimal Essential Medium (DMEM; Invitrogen) and supplemented with non-essential amino acids, $10 \%$ foetal bovine serum, and antibiotics; cells were grown under standard cell culture conditions. The cells were seeded in 6-well plates (Nunc, UK). At $80-85 \%$ confluence, the medium was changed and replaced with fresh medium with vehicle (control) or with medium containing recombinant human IL-6 (10 ng/mL; R\&D Systems, UK) or recombinant human TNF- $\alpha$ (20 ng/mL; R\&D Systems). Both cytokines were reconstituted in sterile PBS containing $0.1 \%$ bovine serum albumin. After treatment, medium was removed and cells were washed with PBS.

\section{RNA extraction and RT-PCR}

RNA was extracted from $\mathrm{HuH7}$ cells and from mouse livers using TRIzol (Invitrogen) according to the manufacturer's instructions. Total RNA $(1 \mu \mathrm{g})$ was reversetranscribed using the Verso cDNA kit (Thermofisher Scientific) as instructed by the manufacturer. RT-PCR was performed using Lightcycler (Roche); human GAPDH and mouse $\beta$-actin were used as internal controls. Duplicate PCR reactions were run for each target gene including GAPDH or $\beta$-actin; each reaction mix contained $1 \mu \mathrm{L}$ of cDNA template, $5 \mathrm{pmol}$ each of 
forward and 5pmol reverse primers, $10 \mu \mathrm{L} 2 \times$ QuantiTect SYBR ${ }^{\circledR}$ Green PCR master mix and water to a final volume of $20 \mu \mathrm{L}$. As a negative control, samples without cDNA were included. The primers used for real-time PCR were synthesised by Sigma-Genosys Ltd. (Poole, $\mathrm{UK}$ ) and are shown in (Table 1). Gene expressions were normalized to that of the GAPDH or $\beta$-actin and represented as $\Delta \mathrm{Ct}$ values. For each sample the mean of the $\Delta \mathrm{Ct}$ values was calculated.

\section{Immunoblotting}

To investigate the effect cytokines on $H J V$ or hepcidin expression, $\mathrm{HuH7}$ cells were either untreated or treated with TNF- $\alpha$ or IL- 6 respectively for 24 hours. Proteins were extracted with RIPA buffer (Santa Cruz) containing protease and phosphatase inhibitors (Sigma); protein content was determined with the Pierce BCA protein assay system. Approximately $50 \mu \mathrm{g}$ aliquots of homogenates were diluted with an equal volume of $2 \times$ Laemmli sample buffer, heated at $40^{\circ} \mathrm{C}$ for $30 \mathrm{~min}$ and resolved on a $12 \%$ polyacrylamide gel (Bio-Rad) at $40 \mathrm{~mA}$. Proteins were transferred onto PVDF membranes (Bio-Rad), using a Bio-Rad Trans-Blot SD semi-dry blotter. After transfer, the blots were washed in distilled water $(3 \times 1$ min) and incubated in 10\% glutaraldehyde overnight. After washing $3 \times 5$ min with distilled water, the membrane was incubated with $5 \%$ non-fat dry milk in PBS-T (PBS/0.1\% Tween 20 ) overnight at $4^{\circ} \mathrm{C}$, with gentle agitation. A 1:2000 or 1: 1000 dilution of affinity-purified anti-hepcidin antibody [33] or anti-HJV antibody (Santa Cruz Biotechnology, UK), respectively was added and then incubated overnight at $4^{\circ} \mathrm{C}$. Membrane blots were then washed $1 \times 15 \mathrm{~min}$ and then a further $3 \times 5 \mathrm{~min}$ with PBS-T, and primary antibodies were probed with an HRP-conjugated secondary IgG at a 1:5000 dilution in PBS-T for 1 hour at room temperature, with continuous rocking. Following secondary antibody incubation, the membrane was washed $3 \times 10$ mins with PBS-T for at room temperature. Detection was performed with the ECL detection kit (Amersham Life Science), in a Fluor-S Multilmager (Bio-Rad). The membrane was also probed with a 1:20,000 dilution of HRP-conjugated anti-actin antibody AC-15 (Abcam) to ascertain equivalent sample loading. Hepatic expression of phosphorylated Smad-1/ $5 / 8$ in saline and LPS injected mice was determined by Western blotting using a 1:500 dilution of a phosphoSmad antibody (Cell signalling, UK).

\section{Generation of HJV promoter-reporter construct}

A portion of the human $H J V$ promoter extending $1.2 \mathrm{~Kb}$ upstream of the beginning of the first $H J V$ exon was amplified by PCR from placental genomic DNA using the PTC-100 thermocycler (MJ Research) and Phusion High- Fidelity DNA Polymerase (New England Biolabs, UK). The following primers were used: sense $5^{\prime}$ CATGCTAGCAAGTGACCCTCCTGCCT CAG, the NheI restriction site is underlined; antisense 5' CATCTCGAGCTGCTGTCTCACTGAGGTCA, the XhoI restriction site is underlined; both were synthesised by Sigma-Genosys Ltd. The PCR reaction mix contained $250 \mathrm{ng}$ of human genomic DNA, forward and reverse primers (final concentration of $0.5 \mu \mathrm{M}$ ), $10 \mu \mathrm{L} 5 \times$ Phusion HF Buffer, $500 \mu \mathrm{M}$ each of dNTPs, 1 unit of Phusion DNA polymerase, and water to a final volume of $50 \mu \mathrm{L}$. The cycling parameters were $98^{\circ} \mathrm{C}$ for 10 seconds (denaturation), $72^{\circ} \mathrm{C}$ for $2 \mathrm{~min}$ (annealing and extension); 35 cycles of PCR were performed with a final extension for $7 \mathrm{~min}$ at $72^{\circ} \mathrm{C}$. The PCR products were digested with NheI-XhoI (New England Biolabs, UK), purified with Geneclean (BIO101, UK), ligated into NheI-XhoI-restricted pGL3 Basic vector (Promega) using the Quick ligation kit (NEB), and transformed into DH5 $\alpha$ competent cells (Invitrogen). Plasmids were purified using Nucleospin plasmid kit

Table 1 Human and mouse primers used for real-time PCR

\begin{tabular}{|c|c|c|}
\hline Primer & Forward (5/—-——————-3') & 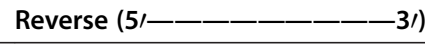 \\
\hline human hepcidin & CTGCAACCCCAGGACAGAG & GGAATAAATAAGGAAGGGAGG \\
\hline human HJV & GGAGCTTGGCCTCTACTGGA & ATGGTGAGCTTCCGGGTG \\
\hline human GAPDH & TGGTATCGTGGAAGGACTC & AGTAGAGGCAGGGATGATG \\
\hline mouse hepcidin 1 & CCTATCTCCATCAACAGATG & AACAGATACCACACTGGGAA \\
\hline mouse $H j v$ & TGCCAGAAGGCTGTGTAAGG & TCTAAATCCGTCAAGAAGACTCG \\
\hline mouse TNF- $a$ & CCAGACCCTCACACTCAGATCA & CACTTGGTGGTTTGCTACGAC \\
\hline mouse IL-6 & AGTTGCCTTCTTGGGACTGA & TCCACGATTTCCCAGAGAAC \\
\hline mouse $B M P-2$ & TGGAAGTGGCCCATTTAGAG & TGACGCTTTCTCGTTTGTG \\
\hline mouse $B M P-4$ & ACGTAGTCCCAAGCATCACC & TCAGTTCAGTGGGGACACAA \\
\hline mouse $B M P-6$ & ATGGCAGGACTGGATCATTGC & CCATCACAGTAGTTGGCAGCG \\
\hline mouse TGF- $\beta$ & CACCGGAGAGCCCTGGATA & TGTACAGCTGCCGCACACA \\
\hline mouse $\beta$-actin & GACGGCCAAGTCATCACTATT & CCACAGGATTCCATACCCAAGA \\
\hline
\end{tabular}


(Macherey-Nagel, Germany), and restricted with NheI and XhoI to identify recombinants. The promoter clone generated, HJVP1.2-luc, was sequenced for verification.

\section{Site-directed mutagenesis of HJVP1.2-luc TNF-a response element (TNFRE)}

A single putative TNFRE, GGC (A/T) GCC, was visually identified in HJVP1.2-luc. To test whether the identified TNFRE was functional, HJVP1.2-luc was subjected to sitedirected mutagenesis using the QuikChange Site-Directed Mutagenesis kit (Stratagene, UK) as instructed by the manufacturer. The mutant primers were as follows: sense TGAAAATGCTGGAGGaAttCTTGGAGTAGGCAGTG and antisense CACTGCCTACTCCAAGaaTtCCTCCAGCATTTTCA; mutated nucleotides (lower case) formed an EcoRI restriction site (underlined) that was used as a marker for successful mutagenesis of HJVP1.2-luc. After initial denaturation for 1 minute at $95^{\circ} \mathrm{C}, \mathrm{PCR}$ cycling parameters were $95^{\circ} \mathrm{C}$ ( 1 minute), $55^{\circ} \mathrm{C}$ ( 1 minute), and $65^{\circ} \mathrm{C}$ (6 minutes), for a total of 18 cycles. Following DpnI digestion of wild-type HJVP1.2-luc, transformation of INV $\alpha F^{\prime}$ competent cells (Invitrogen) with the mutagenesis reaction and selection on LB agar/ampicillin plates, plasmid DNA was purified from overnight cultures of single colonies and digested with EcoRI (New England Biolabs), to distinguish wild-type from mutant HJVP1.2-luc The mutant construct was sequenced for authenticity and was designated mtHJVP1.2-luc.

\section{Transfections and reporter assays}

$\mathrm{HuH7}$ cells were seeded in 24-well plates (Corning) and transfected at $\sim 80-90 \%$ confluence with $200 \mathrm{ng}$ of either HJVP1.2-luc or mtHJVP1.2-luc using Lipofectamine 2000 (Invitrogen); reporter assays were measured and luciferase levels were normalized with respect to $\beta$ galactosidase activity as described previously [34].

\section{Results}

Correlative changes in iron regulatory protein expression during LPS-induced acute inflammation in vivo

Since the premise of our study was to examine how inflammation might cause changes in iron flux, we treated wild-type $\mathrm{C} 57 \mathrm{Bl} / 6$ and $\mathrm{Hfe} \mathrm{KO}$ mice for 6 hours with LPS to induce an acute inflammatory response. We first measured liver mRNA levels of $I L-6$ and TNF$\alpha$ in saline- and LPS- injected mice by RT-PCR. As expected, treatment with LPS significantly increased $I L$ 6 and TNF- $\alpha$ expression levels in the liver of wild-type and $H f e \mathrm{KO}$ mice (Figure 1A). Since these cytokines impact hepcidin and Hjv expression respectively, we determined their mRNA levels as well as those of hepcidin and Hjv in saline- and LPS-injected wild-type and
Hfe KO mice. Treatment with LPS significantly increased hepcidin 1 expression but decreased Hjv expression levels in wild-type and $H f e \quad K O$ mice; their expression profiles were similar in both genotypes (Figure 1B). Moreover, Hfe KO mice showed less hepcidin 1 expression than wild-type animals although this was not statistically significant.

To assess if there was a link between this inflammatory response and the BMP-Smad signalling pathway and whether Hfe might be involved, BMP 2, 4, and 6, and TGF- $\beta$ gene expression levels were also analysed. LPS treatment significantly decreased the mRNA expression levels of $B M P 2, B M P 4$, and BMP6 (Figure 1C) in wild-type and $\mathrm{Hfe} \mathrm{KO}$ mice. However, it had no effect on the expression levels of TGF- $\beta$ and pSmad 1, 5, and 8 protein expression levels in either genotypes (Figure 2A).

Next, we asked whether these changes in iron regulatory gene expression affected liver iron levels. Liver iron content measurement showed that acute inflammation increased hepatic iron content in wild-type mice though not significantly, but there was no change in liver iron in LPS-injected Hfe KO mice which already showed relatively higher liver iron levels compared with both untreated or LPS-treated wild-type animals (Figure 2C).

\section{IL-6 induces hepcidin while TNF- $a$ suppresses HJV expression}

To compare the expression profiles of hepcidin and $H J V$ during the inflammatory response, we treated $\mathrm{HuH} 7$ cells with the pro-inflammatory cytokines, IL- 6 and TNF- $\alpha$ for 24 hours. We found that IL-6 induced a significant increase in hepcidin mRNA (up to 3-fold) but it had no effect on $H J V$ expression (Figure 3A). On the other hand, TNF- $\alpha$ significantly decreased $H J V$ mRNA expression levels in a time-dependent manner but showed no discernible effect on hepcidin mRNA expression (Figure 3B). Maximal repression was observed after 24 hours, and $H J V$ mRNA expression levels returned to normal homeostatic levels after 48 hours (Figure 3C). Next, we asked if the changes in hepcidin and HJV mRNA were reflected in their cognate protein levels. Using immunoblotting, we indeed found that hepcidin protein levels were induced in IL-6 treated cells, while HJV protein levels were significantly reduced in TNF- $\alpha$ treated cells compared to control (Figure 4A\&B).

\section{TNF-a represses HJV transcription}

We identified a single, putative TNF- $\alpha$ response element (TNFRE) in the $H J V$ promoter, 277 nucleotides upstream of the transcription start site (Figure 5A). Similar sequences have been shown to mediate the down-regulation of several human genes in response to TNF- $\alpha$ including osteocalcin, thrombomodulin, alkaline 

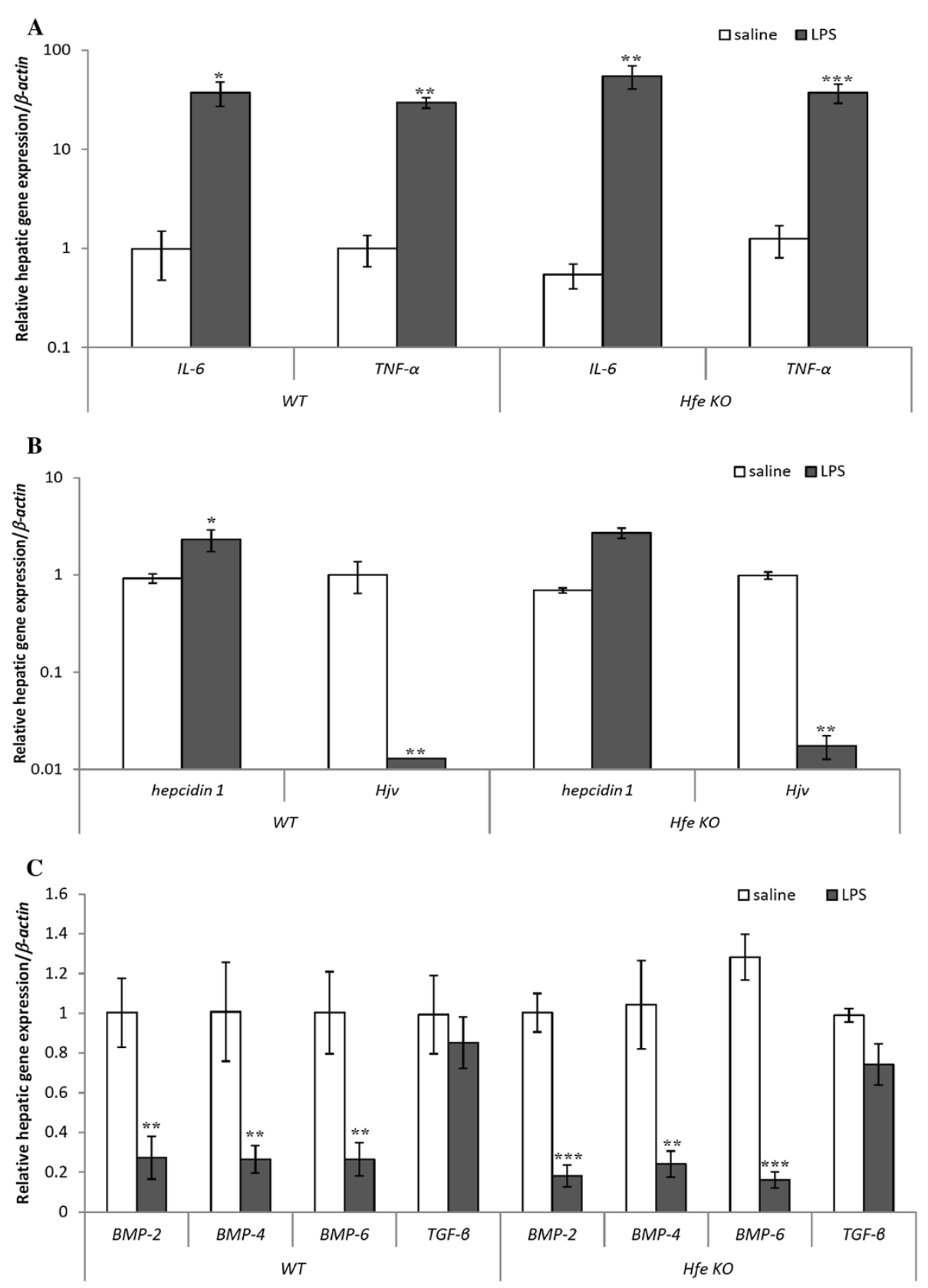

Figure 1 Effect of acute inflammation on hepatic gene expression in wild-type and Hfe KO mice. A) IL-6 and TNF- $a$ mRNA expression levels were analysed by real time PCR. B) Hepcidin 1 and Hjv mRNA levels were analysed by RT-PCR. C) BMP-2, BMP-4, BMP-6, and TGF- $\beta$ mRNA expression were analysed by RT-PCR. Data are mean \pm SEM $(n=5) .{ }^{*} p<0.05,{ }^{* *} p<0.01$, ${ }^{* * *} p<0.001$ in LPS-injected mice compared to saline-injected controls.

phosphatase, and c-myc [35-38]. To test if a similar mechanism might underlie $H J V$ regulation, we transfected HuH7 cells with HJVP1.2-luc. Luciferase assays showed that the basal luciferase activity of HJVP1.2-luc was inhibited by about $40 \%$ following TNF- $\alpha$ treatment (Figure $5 \mathrm{~B}$ ), suggesting that the cloned promoter region was responsive to TNF- $\alpha$. In order to ascertain whether this site was functional and responsible for TNF- $\alpha$ suppression of $H J V$ expression, it was deleted by site-directed mutagenesis to

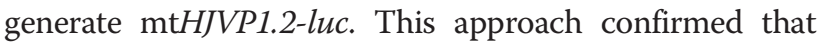
the TNFRE alone within HJVP1.2-luc was sufficient for $H J V$ down-regulation by TNF- $\alpha$ because its deletion abolished TNF- $\alpha$ responsiveness whereas the wild-type promoter was repressed by this cytokine (Figure 6). These data strongly suggest that TNF- $\alpha$ suppresses the transcription of $H J V$ through this RE. 


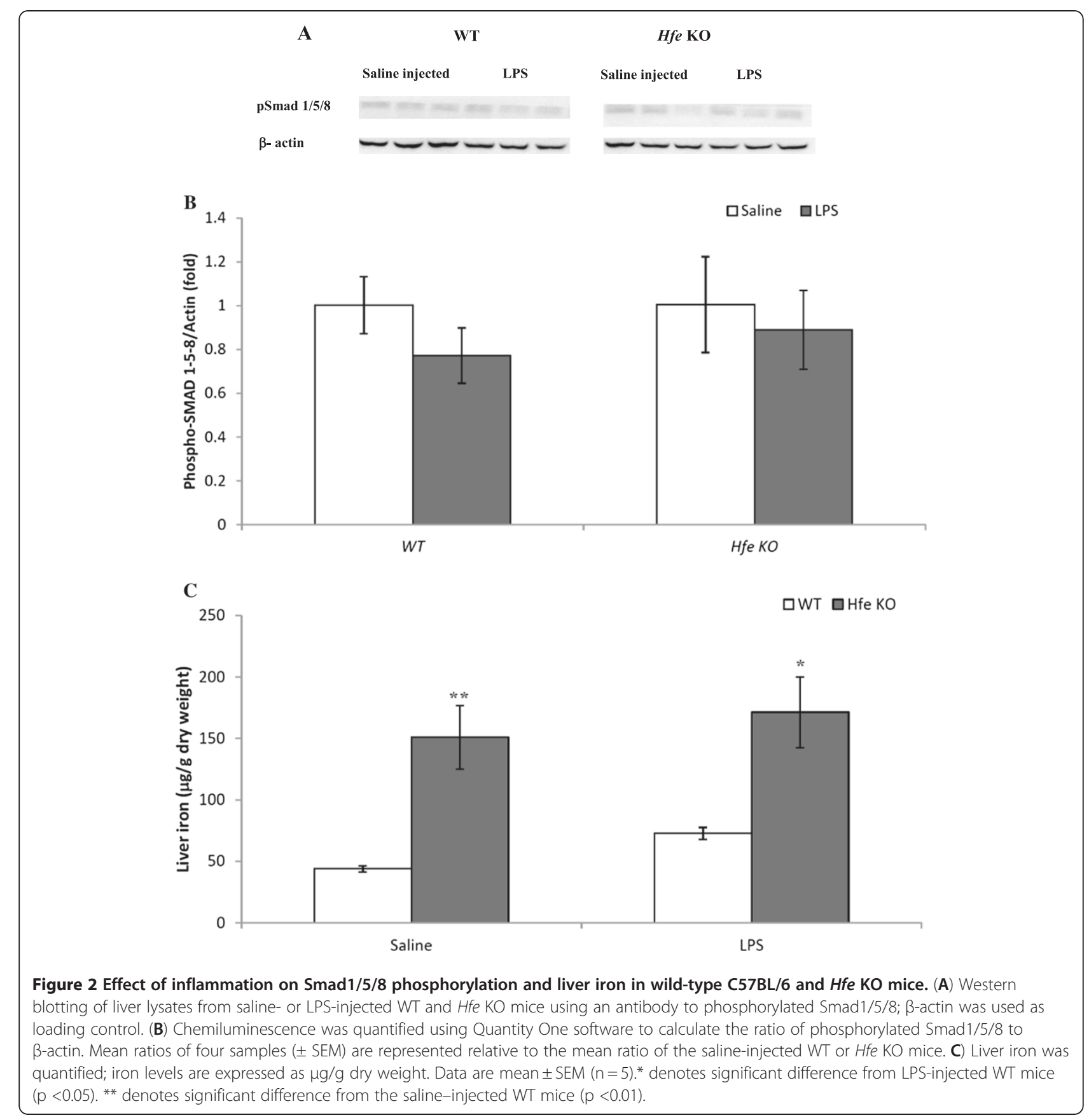

\section{Discussion}

The thrust of our study was to gain some understanding of how inflammation might induce changes in the expression of genes that regulate iron metabolism, and to evaluate and extrapolate some possible consequences that might have in human disease. First, we investigated hepcidin 1 and Hjv expression in $\mathrm{C} 57 \mathrm{Bl} / 6$ mice during acute inflammation. The results showed that LPS induced hepcidin 1 expression in mice in accordance with previous reports [30,39], but decreased the expression of $H j v, B M P-2, B M P-4$, and
$B M P-6$ in the liver. Decreased expression of Hjv by LPS is in agreement with previous reports [32,40]. Hfe did not appear to contribute to the regulation of these genes during inflammation because there were no differences in hepcidin1 expression between wild-type and knockout mice; this is consistent with other findings $[29,30]$ but is in sharp contrast to other reports where inflammation induced with a lower dose of LPS than the one used in this study reported blunted expression of hepcidin in Hfe $\mathrm{KO}$ mice [17]. 

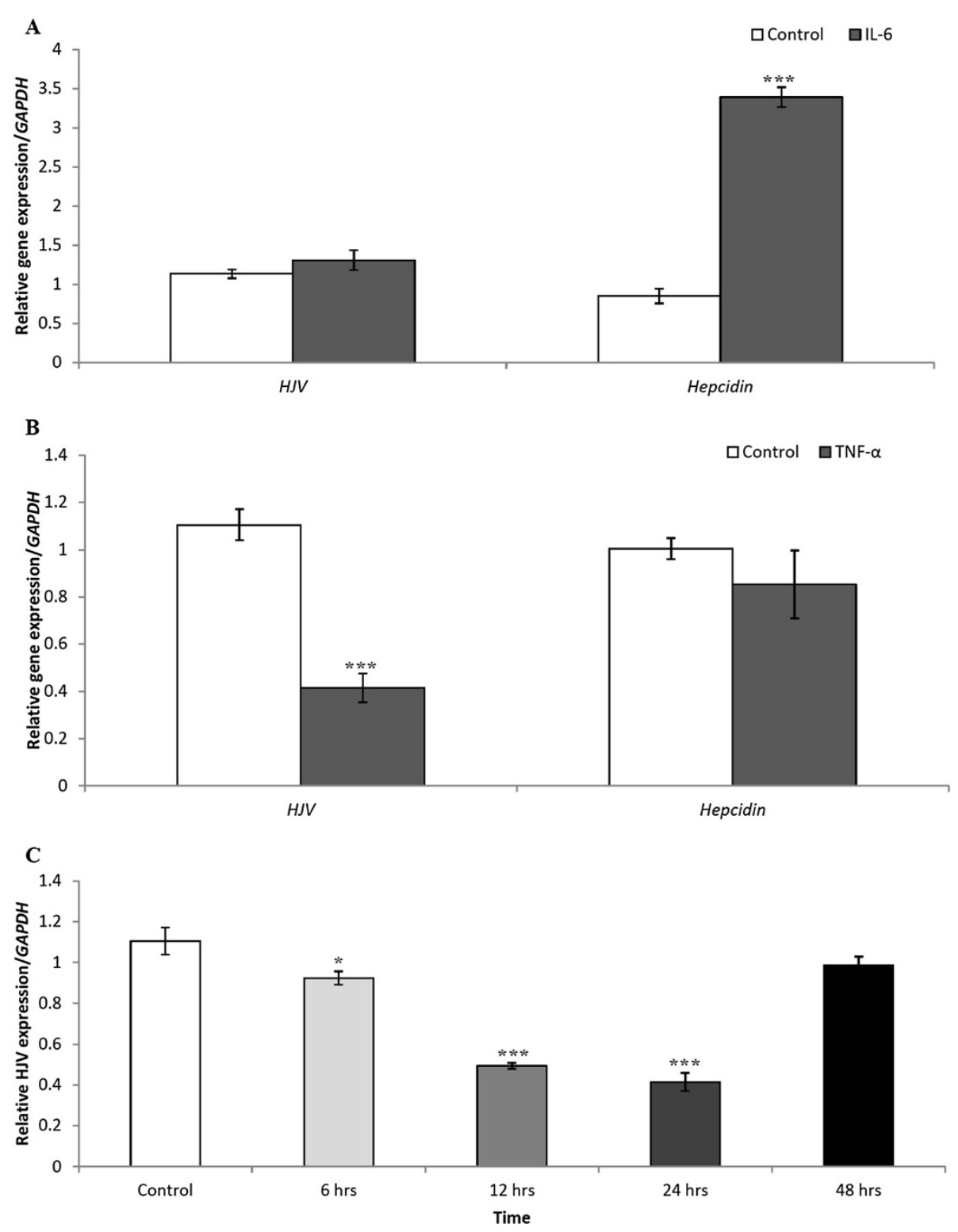

Figure 3 Quantitative RT-PCR analysis of hepcidin and HJV mRNA expression in HuH7 cells following IL-6 and TNF-a treatment. A) $\mathrm{HuH7}$ cells were incubated for 24 hours in the presence of vehicle (control) or $\mathrm{IL}-6(10 \mathrm{ng} / \mathrm{mL}$ ). B) HuH7 cells were incubated for 24 hours in the presence of vehicle (control) or TNF-a $(20 \mathrm{ng} / \mathrm{mL})$ and quantitative PCR was performed for hepcidin and HJV gene expression. Data are mean \pm SEM of 6 samples from 3 separate experiments performed in duplicate. ${ }^{* *} p<0.001$. (C) HuH7 cells were incubated in the presence of vehicle (control) or TNF-a (20 ng/mL) for 6, 12, 24, and 48 hours. Quantitative PCR for HJV mRNA expression was performed for 6 samples, each run in triplicates, in 2 separate experiments. Data are mean \pm SEM . ${ }^{*} p<0.05,{ }^{* * *} p<0.001$.

The direct regulation of hepcidin and $H J V$ expression by pro-inflammatory cytokines was also examined in vitro using a human hepatoma cell line (HuH7). These cells were also used to study the mechanism of $H J V$ regulation during inflammation using a $H J V$ promoter-reporter construct. We found that TNF- $\alpha$, but not IL-6, mediated $H J V$ down-regulation during inflammation, whereas IL-6 was required to induce hepcidin expression in HuH7 cells. Hepatic Hjv expression was also down-regulated by LPS in wild-type and Hfe KO mice, consistent with other reports [40]. These data imply that the ability to down-regulate $H j v$ expression during the acute phase response remains intact even in the absence of functional Hfe. Our results also showed that TNF- $\alpha$-induced $H J V$ suppression was mediated by a TNF- $\alpha$ response element within the $H J V$ promoter.

It is well established that BMPs induce hepcidin expression through Smad signalling via a common mediator, 


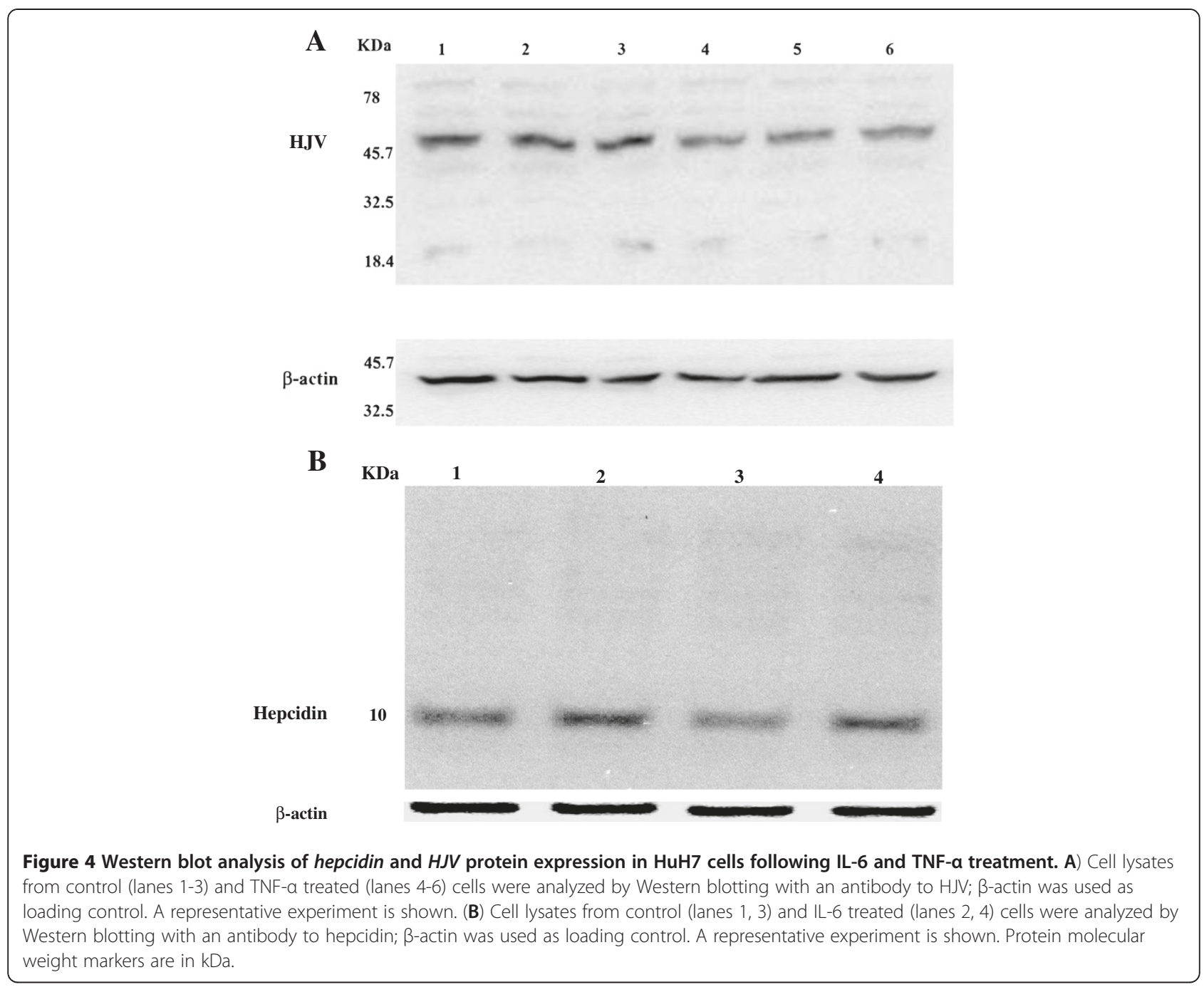

Smad-4 [25,41]. However, in mice with targeted disruption of Smad-4 in the liver, the response of hepcidin to inflammatory stimulation was blunted [41]. Moreover, a recently identified BMP-responsive element within the hepcidin gene promoter was found to be not only important for the BMP response but also for IL-6 responsiveness [28]. These data suggest that there might be cross-talk between the IL-6 and the BMP-Smad signalling pathways. We therefore investigated the possible interaction between inflammation and BMP/Smad signalling in LPS-induced acute inflammation in wild-type and $\mathrm{Hfe} \mathrm{KO}$ mice. Because BMPs transmit signals through phosphorylation of Smad1, Smad5 and Smad8, the relative abundance of the phosphorylated forms of these three Smads was also quantified in liver extracts of LPS- and saline- injected wild-type and $\mathrm{Hfe} \mathrm{KO}$ mice by Western blot analysis. Interestingly, we found that $B M P-2, B M P-4$, and BMP-6 mRNA expression levels were down-regulated during acute inflammation in wild-type and $H f e \mathrm{KO}$ mice but there was no change in phosphorylated Smad1/5/8 expression in the liver. In addition, no change was observed in TGF- $\beta$ expression in response to inflammation that could maintain the basal expression levels of phosphorylated Smads [42]. These findings suggest that BMPs are not required for hepcidin induction during inflammation; we propose that if there is any link between inflammation and Smad signalling, it probably lies downstream of BMP ligands, and is probably Hfe-independent. To our knowledge, this is the first demonstration that $B M P$ expression may be influenced by inflammation in vivo; however, the exact mechanism and its implication need further investigation.

LPS is recognized by Toll-like receptor (TLR) 4 which, upon activation, produces pro-inflammatory cytokines such as TNF- $\alpha$, IL-1, and IL-6 through NFkB $[43,44]$. Given this information, it is unclear why the same ligand (LPS) or signalling pathway produces cytokines that have variable effects on hepcidin expression, i.e. that IL-6, but not TNF- $\alpha$, induces hepcidin during inflammation. Our observation that TNF- $\alpha$ repressed $H J V$ in liver cells strongly suggests that these cytokines impact hepcidin and 
A

-499 TTCGTCCTTC TGAAATACTC TGCAAAGATA GGAGAGGGGC TATGAACTAC

-449 CTCTGCTATG GATCTTATTC AAAGTCAGCT ACCTCCTAGA TACTATCTGT

-399 AGAACCTAAA TGTAATATTC AGCATAGCAG GGATGAACAT GGTAAATGAA

-349 AGGTATCCAA TTGCCCACTG TAATTTTTAA AGGCCAGGAG CTCAACATTA

-299 TTGAAAATGC TGGAGGGCTg CCTGGAGTAg GCAGTGACCA CAGAGTCACA

-249 CAAGCTGGAA TTGGATATCC AACTTGTCTG TCATATTTCT CTCCTCCCTC

-199 CCTGACTTGG CACTCAATAC TCCATATTCT TTCTAATCCT CTAACCCTCC

-149 CCACTCCCCC AACTCCCACA CCCTACCCCC ACCAACGTTC CTGGAATTTT

-99 GGACTTAGCT ATTTTTAAAA CCGTCAACTC AGTAGCCACC TCCCTCCCTG

- 49 CTCAGCTGTC CAGTACTCTG GCCAGCCATA TACTCCCCCT TCCCCCCATA

+2 CCAAACCTTC TCTGGTTCCC TGACCTCAGT GAGACAGCAG

B

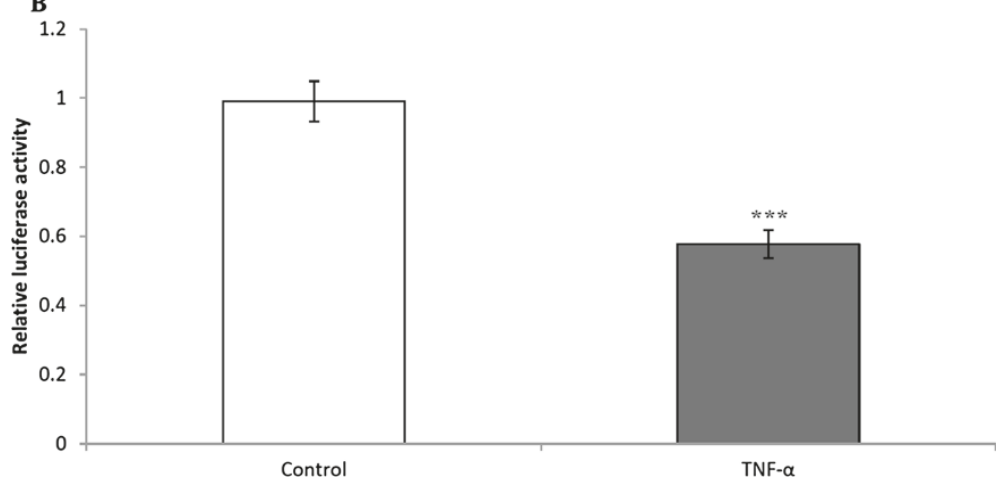

Figure 5 Genomic context of the TNFRE in the HJV promoter; and luciferase reporter activity of HJVP1.2-luc transfected HuH7 cells following TNF-a treatment. A) The consensus TNF-a RE (underlined) lies 277 nucleotides upstream of the transcription start site (bold italic). (B) HuH7 cells were transfected with HJVP1.2-luc and incubated for 24 hours with TNF-a (20 ng/ml). Luciferase expression in both treated and untreated cells were normalized to $\beta$-galactosidase expression. Data are mean $\pm \mathrm{SEM}, \mathrm{n}=12$ from 3 separate experiments; ${ }^{* *} \mathrm{p}<0.0001$.

iron regulation in very different ways. This TNF- $\alpha-$ mediated down-regulation of $H J V$ expression is not only in accord with other previous findings [40] but also extends them with (our) new data which show that TNF- $\alpha$ uniquely drives $H J V$ repression through a response element in the promoter of this gene. Mutational analysis confirmed that this element was indeed necessary and sufficient for TNF- $\alpha$ responsiveness. An added complication is the role of the BMPs in modulating hepcidin expression through $\mathrm{HJV}$ and at present it is unclear how the interplay between TNF- $\alpha$ on one hand and the BMPs on the other, affects hepcidin expression through HJV. However, this conundrum appears to have been resolved by recent findings that mice lacking either Hjv or $B m p-6$ retained the ability to induce hepcidin in response to inflammatory stimuli $[26,45]$; this indicates that neither

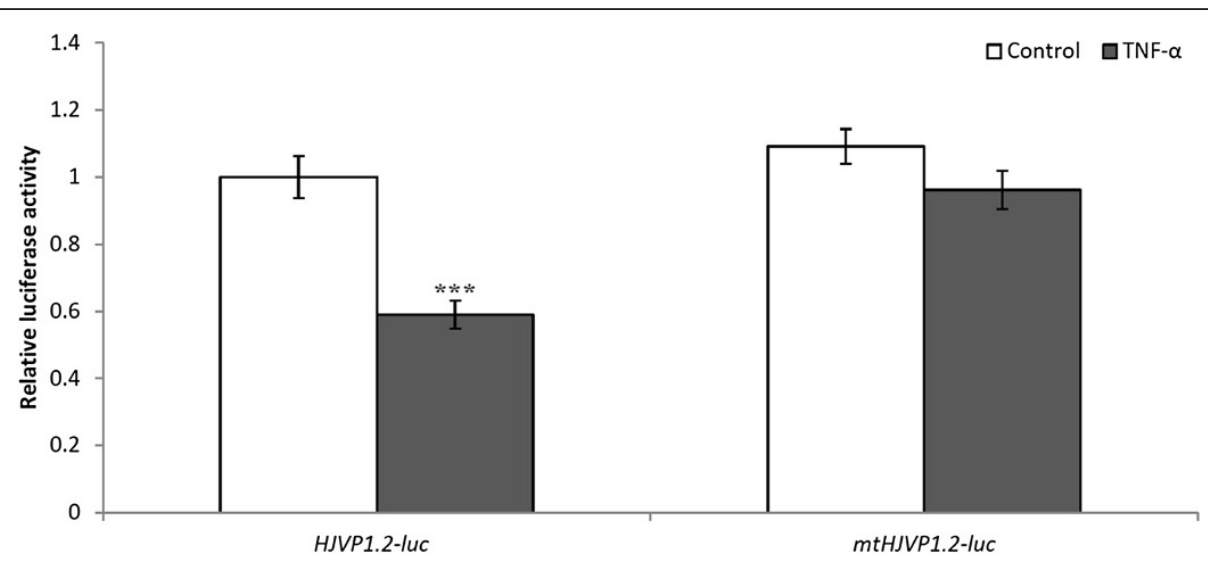

Figure 6 Luciferase reporter activity of HJVP1.2-luc and mtHJVP1.2-luc transfected HuH7 cells following TNF-a treatment. HuH7 cells were transfected with HJVP1.2-luc or mtHJVP1.2-luc to verify that the identified TNFRE is functional. Transfected HuH7 cells were incubated for 24 hours in the presence of TNF-a $(20 \mathrm{ng} / \mathrm{ml})$. Data are mean \pm SEM, $\mathrm{n}=12$ of 3 independent experiments. ${ }^{* *} \mathrm{p}<0.0001$. 
Hjv nor BMP-6 is required for hepcidin response to inflammation. However, both Hjv and BMP-6 have been shown to be required for iron sensing by hepcidin.

On the basis of our observations we propose a mechanism (Figure 7) in which iron flux through HJV-BMPSmad signalling is curtailed by LPS-induced TNF- $\alpha$. The fundamental reason (see below) for such a control is not only interesting in itself but also because TNF- $\alpha$ is a firstresponder, its expression is transient (being maximal at about 2 hours after LPS treatment), and returning to basal levels by 6 hours [46]; the latter time-point coincides with maximal acute phase response by the liver when hepcidin is most expressed. Since soluble HJV is a potent repressor of hepcidin expression [41], it would therefore appear that TNF- $\alpha$ constrains $H J V$ expression in order to enable subsequent hepcidin induction in the acute phase response through IL-6/Stat3 signalling. In other words, TNF- $\alpha$ simply serves as an initiator and to prime hepcidin expression in the acute phase response through IL1 $\beta$ and IL- 6 which are integral to that process. Our model is supported by recent observations that mice lacking Bmp-6 [47] which signals through Hjv, still retained the ability to express hepcidin in response to LPS precisely because the early response phase had been by-passed or because the BMP- 6 and IL- 6 pathways are separable but convergent, i.e. there may be cross-talk between these two disparate pathways [28]. Taken together with other findings, our results may improve our understanding of how this cross-talk (or lack of it) may determine how hepcidin expression is regulated by infection/ inflammation [48]. However, how that may determine the development and course of the anaemia that results, and the search for small-molecule antagonists that target this pathway needs further investigation.

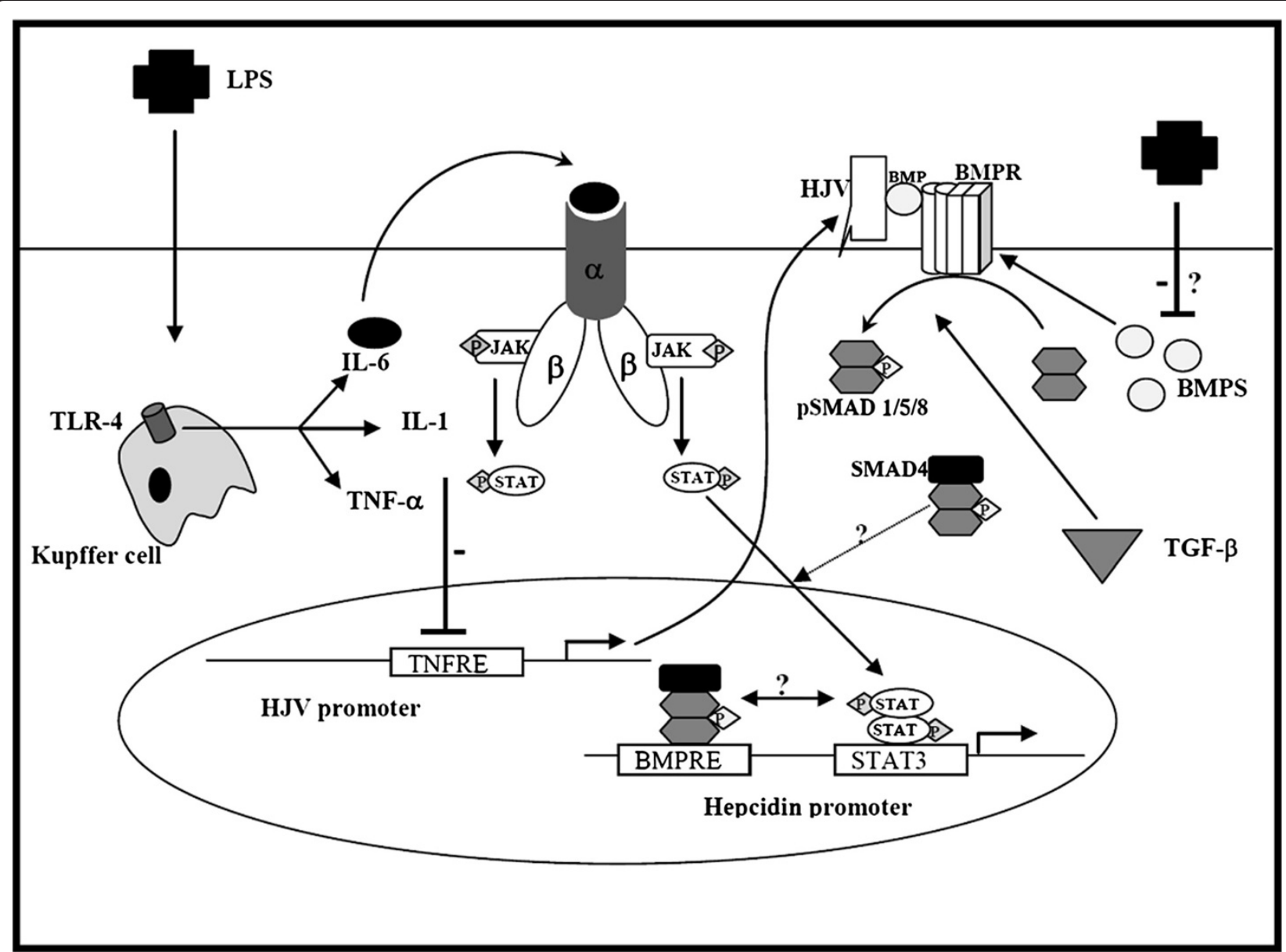

Figure 7 Proposed mechanism of the inter-relationship between hepcidin and HJV expression during the inflammatory response, and the effect on iron flux. LPS is taken up by Kupffer cells via TLR-4 and induces TNF-a, IL-1, and IL-6. TNF-a suppresses HJV expression via a TNFRE within the HJV promoter, while IL-6 induces hepcidin expression via the STAT3 pathway. LPS also represses the expression of BMPS $(2,4$, and 6), via an as yet unknown mechanism. Thus, iron sensing by the BMPs, HJV and BMP receptor involved in regulating hepcidin is abrogated whereas inflammatory signalling by IL-6 through hepcidin remains intact. 


\section{Conclusion}

Our results demonstrate that TNF- $\alpha$ suppresses $H J V$ transcription via a novel TNFRE within its promoter. We propose that the link between inflammation and BMP-SMAD signalling is downstream of HJV and BMP ligands; this link and its implication need further studies.

\section{Competing interests}

The authors declare no competing interests.

\section{Authors' contribution}

MFS designed, performed experiments and wrote the manuscript. SKS designed experiments and edited the manuscript. HKB critically reviewed and approved the manuscript. All authors read and approved the final manuscript.

\section{Acknowledgements}

The authors are grateful to Dr. Bala Ramesh for his help with hepcidin Western Blotting. M.F.S. was supported by a scholarship from the Egyptian Government (Ministry of Higher Education, Egypt).

Received: 2 April 2012 Accepted: 30 August 2012

Published: 21 September 2012

\section{References}

1. Cartwright GE, Wintrobe MM: The anemia of infection. XVII. A review. AdV Intern Med 1952, 5:165-226.

2. Cartwright GE: The anemia of chronic disorders. Semin Hematol 1966 3:351-375.

3. Lee GR: The anemia of chronic disease. Semin Hematol 1983, 20:61-80.

4. Cortell S, Conrad ME: Effect of endotoxin on iron absorption. Am J Physiol 1967, 213:43-47.

5. Cartwright GE, Lee GR: The anaemia of chronic disorders. Br J Haematol 1971, 21:147-152

6. Weinberg ED: Iron depletion: a defense against intracellular infection and neoplasia. Life Sci 1992, 50:1289-1297.

7. Jurado RL: Iron, infections, and anemia of inflammation. Clin Infect Dis 1997, 25:888-895.

8. Moldawer LL, Marano MA, Wei H, Fong Y, Silen ML, Kuo G, Manogue KR, Vlassara H, Cohen H, Cerami A, Lowry SF: Cachectin/tumor necrosis factoralpha alters red blood cell kinetics and induces anemia in vivo. FASEB $J$ 1989, 3:1637-1643

9. Johnson D, Bayele H, Johnston K, Tennant J, Srai SK, Sharp P: Tumour necrosis factor alpha regulates iron transport and transporter expression in human intestinal epithelial cells. FEBS Lett 2004, 573:195-201.

10. Ludwiczek S, Aigner E, Theurl I, Weiss G: Cytokine-mediated regulation of iron transport in human monocytic cells. Blood 2003, 101:4148-4154.

11. Yang F, Liu XB, Quinones M, Melby PC, Ghio A, Haile DJ: Regulation of reticuloendothelial iron transporter MTP1 (SIc11a3) by inflammation. J Biol Chem 2002, 277:39786-39791.

12. Wrighting DM, Andrews NC: Interleukin-6 induces hepcidin expression through STAT3. Blood 2006, 108:3204-3209.

13. Truksa J, Peng H, Lee $P$, Beutler E: Different regulatory elements are required for response of hepcidin to IL- 6 and bone morphogenetic proteins BMP 4 and 9. Br J Haematol 2007, 139:138-147.

14. Verga Falzacappa MV, Vujic Spasic M, Kessler R, Stolte J, Hentze MW Muckenthaler MU: STAT-3 mediates hepatic hepcidin expression and its inflammatory stimulation. Blood 2007, 109:353-358.

15. Roy CN, Andrews NC: Anemia of inflammation: the hepcidin link. Curr Opin Hematol 2005, 12:107-111.

16. Laftah AH, Ramesh B, Simpson RJ, Solanky N, Bahram S, Schumann K, Debnam ES, Srai SK: Effect of hepcidin on intestinal iron absorption in mice. Blood 2004, 103:3940-3944.

17. Roy CN, Custodio AO, de Graaf J, Schneider S, Akpan I, Montross LK, Sanchez M, Gaudino A, Hentze MW, Andrews NC, Muckenthaler MU: An Hfe-dependent pathway mediates hyposideremia in response to lipopolysaccharide-induced inflammation in mice. Nat Genet 2004 36:481-485.

18. Yamaji S, Sharp P, Ramesh B, Srai SK: Inhibition of iron transport across human intestinal epithelial cells by hepcidin. Blood 2004, 104:2178-2180.
19. Chung B, Chaston T, Marks J, Srai SK, Sharp PA: Hepcidin decreases iron transporter expression in vivo in mouse duodenum and spleen and in vitro in THP-1 macrophages and intestinal Caco-2 cells. J Nutr 2009, 139:1457-1462.

20. Nemeth E, Rivera S, Gabayan V, Keller C, Taudorf S, Pedersen BK, Ganz T: IL-6 mediates hypoferremia of inflammation by inducing the synthesis of the iron regulatory hormone hepcidin. J Clin Invest 2004, 113:1271-1276.

21. Kemna E, Pickkers $P$, Nemeth E, van der Hoeven H, Swinkels D: Time-course analysis of hepcidin, serum iron, and plasma cytokine levels in humans injected with LPS. Blood 2005, 106:1864-1866.

22. Sheikh N, Dudas J, Ramadori G: Changes of gene expression of iron regulatory proteins during turpentine oil-induced acute-phase response in the rat. Lab Invest 2007, 87:713-725.

23. Nicolas G, Chauvet C, Viatte L, Danan JL, Bigard X, Devaux I, Beaumont C, Kahn A, Vaulont $S$ : The gene encoding the iron regulatory peptide hepcidin is regulated by anemia, hypoxia, and inflammation. J Clin Invest 2002, 110:1037-1044.

24. Ganz T: Hepcidin, a key regulator of iron metabolism and mediator of anemia of inflammation. Blood 2003, 102:783-788.

25. Babitt JL, Huang FW, Wrighting DM, Xia Y, Sidis Y, Samad TA, Campagna JA, Chung RT, Schneyer AL, Woolf CJ, Andrews NC, Lin HY: Bone morphogenetic protein signaling by hemojuvelin regulates hepcidin expression. Nat Genet 2006, 38:531-539.

26. Niederkofler $V$, Salie R, Arber S: Hemojuvelin is essential for dietary iron sensing, and its mutation leads to severe iron overload. J Clin Invest 2005, 115:2180-2186.

27. Wang RH, Li C, Xu X, Zheng Y, Xiao C, Zerfas P, Cooperman S, Eckhaus M, Rouault T, Mishra L, Deng CX: A role of SMAD4 in iron metabolism through the positive regulation of hepcidin expression. Cell Metab 2005, 2:399-409.

28. Verga Falzacappa MV, Casanovas G, Hentze MW, Muckenthaler MU: A bone morphogenetic protein (BMP)-responsive element in the hepcidin promoter controls HFE2-mediated hepatic hepcidin expression and its response to IL-6 in cultured cells. J Mol Med 2008, 86:531-540.

29. Lee PL, Peng H, Gelbart T, Beutler E: The IL-6- and lipopolysaccharideinduced transcription of hepcidin in $H F E$, transferrin receptor-2, and $\beta 2$ microglobulin deficient hepatocytes. Proc Natl Acad Sci USA 2004, 101:9263-9265.

30. Constante M, Jiang W, Wang D, Raymond VA, Bilodeau M, Santos MM: Distinct requirements for $\mathrm{Hfe}$ in basal and induced hepcidin levels in iron overload and inflammation. Am J Physiol Gastrointest Liver Physiol 2006, 291:G229-G237.

31. Yeh KY, Yeh M, Glass J: Hepcidin regulation of ferroportin 1 expression in the liver and intestine of the rat. Am J Physiol Gastrointest Liver Physiol 2004, 286:G385-G394.

32. Krijt J, Vokurka M, Chang KT, Necas E: Expression of Rgmc, the murine ortholog of hemojuvelin gene, is modulated by development and inflammation, but not by iron status or erythropoietin. Blood 2004, 104:4308-4310.

33. Balesaria S, Ramesh B, McArdle H, Bayele HK, Srai SK: Divalent metaldependent regulation of hepcidin expression by MTF-1. FEBS Lett 2010, 584(4):719-725.

34. Bayele HK, McArdle H, Srai SK: Cis and trans regulation of hepcidin expression by upstream stimulatory factor. Blood 2006, 108:4237-4245.

35. Li YP, Stashenko P: Characterization of tumor necrosis factor-responsive element which down-regulates the human osteocalcin gene. $\mathrm{Mol} \mathrm{Cell} \mathrm{Biol}$ 1993, 13:3714-3721.

36. Ohdama S, Takano S, Ohashi K, Miyake S, Aoki N: Pentoxifylline prevents tumor necrosis factor-induced suppression of endothelial cell surface thrombomodulin. Thrombosis Res 1991, 62:745-755.

37. Weiss MJ, Henthorn PS, Ray K, Lamb B, Kadesch T, Harris H: Structure of the human liver/bone/kidney alkaline phosphatase gene. J Biol Chem 1988, 263:12002-12010.

38. Watt R, Nishikura K, Sorrentino J, Ar-Rushdi A, Croce CM, Rovera G: The structure and nucleotide sequence of the 5 / end of the human c-myc oncogene. Proc Natl Acad Sci USA 1983, 80:6307-6311.

39. Pigeon C, llyin G, Courselaud B, Leroyer $P$, Turlin B, Brissot $P$, Loréal O: A new mouse liver-specific gene, encoding a protein homologous to human antimicrobial peptide hepcidin, is over-expressed during iron overload. J Biol Chem 2001, 276:7811-7819. 
40. Constante M, Wang D, Raymond VA, Bilodeau M, Santos MM: Repression of repulsive guidance molecule $\mathrm{C}$ during inflammation is independent of Hfe and involves tumor necrosis factor-alpha. Am J Pathol 2007, 170:497-504.

41. Babitt JL, Huang FW, Xia Y, Sidis Y, Andrews NC, Lin HY: Modulation of bone morphogenetic protein signaling in vivo regulates systemic iron balance. J Clin Invest 2007, 117:1933-1939.

42. Breitkopf $\mathrm{K}$, Weng $\mathrm{H}$, Dooley S: TGF- $\beta$ /Smad-signalling in liver cells: Target genes and inhibitors of two parappel pathways. Signal Transduct 2006, 6:329-337.

43. Hoshino K, Takeuchi O, Kawai T, Sanjo H, Ogawa T, Takeda Y, Takeda K, Akira S: Cutting edge: Toll-like receptor 4 (TLR4)-deficient mice are hyporesponsive to lipopolysaccharide: evidence for TLR4 as the Lps gene product. J Immunol 1999, 162:3749-3752.

44. Aderem A, Ulevitch RJ: Toll-like receptors in the induction of the innate immune response. Nature 2000, 406:782-787.

45. Nemeth E, Valore EV, Territo M, Schiller G, Lichtenstein A, Ganz T: Hepcidin, a putative mediator of anemia of inflammation, is a type II acute-phase protein. Blood 2003, 101:2461-2463.

46. Michishita M, Yoshida Y, Uchino H, Nagata K: Induction of tumor necrosis factor-alpha and its receptors during differentiation in myeloid leukemic cells along the monocytic pathway. A possible regulatory mechanism for TNF-alpha production. J Biol Chem 1990, 265(15):8751-8759.

47. Meynard D, Kautz L, Darnaud V, Canonne-Hergaux F, Coppin H, Roth MP: Lack of the bone morphogenetic protein BMP6 induces massive iron overload. Nat Genet 2009, 41:478-481.

48. Malyszko J: Hemojuvelin: the hepcidin story continues. Kidney Blood Press Res 2009, 32:71-76.

doi:10.1186/1423-0127-19-83

Cite this article as: Salama et al:: Tumour necrosis factor alpha downregulates human hemojuvelin expression via a novel response element within its promoter. Journal of Biomedical Science 2012 19:83.

\section{Submit your next manuscript to BioMed Central and take full advantage of:}

- Convenient online submission

- Thorough peer review

- No space constraints or color figure charges

- Immediate publication on acceptance

- Inclusion in PubMed, CAS, Scopus and Google Scholar

- Research which is freely available for redistribution 